\title{
New concepts in the diagnosis and pathogenesis of Trichomonas vaginalis
}

\author{
Renuka Bhatt PhD, Mary Abraham mSc, Dino Petrin hbSc, Gary E Garber mD frCPC
}

\begin{abstract}
R BHATT, M ABRAHAM, D PETRIN, GE GARBER. New concepts in the diagnosis and pathogenesis of Trichomonas vaginalis. Can J Infect Dis 1996;7(5):321-325. Trichomonas vaginalis infection is the most commonly encountered sexually transmitted disease. There is a need for more accurate and rapid laboratory diagnostic methods, leading to better control and treatment strategies. Various virulence factors such as adherence, contact-independent factors, hemolysis and acquisition of host macromolecules have been shown to play a role in the pathogenesis of this infection. Detection of the factors that are only present in the pathogenic isolates of trichomonads will lead to a better understanding of the epidemiology of this pathogen. Culture technique is highly specific compared with microscopic techniques, but it is time consuming. Immunological techniques lack proper correlation with clinical manifestations. The application of monoclonal antibodies, either singly or in a group that recognizes a common antigen, along with methods such as detection of common DNA fragment from clinical specimens, may have a promising future in the laboratory diagnosis of trichomoniasis.
\end{abstract}

Key Words: Cell detaching factor, Cysteine protease, Trichomonas vaginalis

\section{Nouveaux concepts dans le diagnostic et la pathogenèse de l'infection à Trichomonas vaginalis}

RÉSUMÉ : L'infection à Trichomonas vaginalis est la plus répandue des maladies transmises sexuellement. Il faut mettre au point des méthodes diagnostiques plus précises et plus rapides pour en arriver à des stratégies thérapeutiques et prophylactiques meilleures. Divers facteurs de virulence comme l'adhésivité, les facteurs indépendants du contact, l'hémolyse et l'acquisition des macromolécules de l'hôte ont un rôle important à jouer dans la pathogenèse de cette infection. Le dépistage des facteurs qui ne sont présents que dans les isolats pathogènes de Trichomonas amènera une meilleure compréhension de l'épidémiologie de ce pathogène. La technique de culture est très spécifique si on la compare aux techniques microscopiques, mais elle prend du temps. Les techniques immunologiques ne sont pas en très bonne corrélation avec les manifestations cliniques. L'application des anticorps monoclonaux, soit seuls ou en groupes, qui reconnaissent un antigène commun, de même que les méthodes comme le dépistage de fragment commun d'ADN à partir de spécimen cliniques pourraient receler d'importantes promesses pour le diagnostic de l'infection à Trichomonas.

$\mathrm{S}$ exually transmitted diseases (STDs) constitute a group of infections that have long been an integral part of society. Trichomonas vaginalis infection is the most common STD $(1,2)$. T vaginalis is a protozoan parasite that infects both men and women, especially during their sexually active years. In men, the infection is usually asymptomatic (3). In women, trichomoniasis exhibits a wider variety of symptoms than any other vaginal infection and the symptoms may range from mild to severe; from the short-lived to the chronic; and from an isolated incident to the persistently recurrent (4). Complications due to trichomonal infection include adverse pregnancy outcome $(5,6)$, low birth weight, postpartum endometritis (7), premature rupture of membranes (8), preterm delivery (9) and facilitation of human immunodeficiency virus (HIV) transmission (10). T vaginalis has adapted well to the continuously changing environment of the vagina. Recent research has

Department of Medicine and Microbiology and Immunology, University of Ottawa, Ottawa, Ontario

Correspondence and reprints: Dr G Garber, Division of Infectious Diseases, Department of Medicine, Ottawa General Hospital, Ottawa,

Ontario K1H 8L6. Telephone 613-737-8173, fax 613-737-8099, e-mail ggarber@ogh.on.ca

Received for publication March 20, 1996. Accepted March 22, 1996 
started to elucidate this dynamic interaction, helping to explain various aspects of its pathogenicity. These advances may lead to more sensitive techniques for diagnosis.

\section{CULTURE AND SLIDE-BASED TECHNIQUES OF DIAGNOSIS}

Direct wet-mount of fresh material and culture techniques are the most widely used techniques in diagnosis of trichomoniasis. Despite the advantage of immediate diagnosis by wet preparation, successful use of the method depends on the collection of the specimen, the amount of material on the swab, and the presence and the number of motile parasites. The sensitivity of wet preparation ranges from as low as $38 \%$ to as high as $82 \%$ (11). The insensitivity of the test is in part due to rapid loss of the characteristic motility by which this organism is identified and the presence of very few parasites. The wet preparation technique requires the presence of at least $10^{4}$ organisms/mL to give positive results.

Various staining techniques such as Giemsa (12), acridine orange (13) and Papanicolaou (14) were introduced to improve the sensitivity of direct microscopy. However, staining techniques have their own limitations because the typical morphological characteristic of trichomonads are lost during fixation and staining steps. The inconsistency in the size and shape of the organisms, which on occasion may resemble polymorphonuclear leukocytes (which are present in abundance in vaginitis), adds to the difficulty in interpreting stained smears.

The broth culture method is described as the 'gold standard' for the diagnosis of trichomoniasis because it is simple to interpret and the technique detects the presence of comparatively very few organisms; however, it requires 48 to $72 \mathrm{~h}$ of incubation $(15,16)$.

The cell culture technique was introduced by Hogue (17) in 1943 to study the cytopathic effect of this parasite. Since then numerous investigators have attempted to study this effect in various cell lines. Garber et al (18) used McCoy cells for the cultivation of clinical specimens of $\mathrm{T}$ vaginalis and showed it to be superior to wet preparation. They also showed that cell culture could assist in differentiating pathogenic isolates from nonpathogenic isolates. Kulda (19) and Alderete and Pearlman (20) offered support for this view when they observed that nonpathogenic isolates of trichomonad species failed to disrupt the cell culture monolayer. Most of the cell culture studies demonstrated that physical contact with cells was a major factor in the pathogenicity of $\mathrm{T}$ vaginalis. However, chemical secretable factors produced directly or indirectly (production of acidic metabolites by the living organisms can lead to hemolysis or death of cultured cells) (21) by the trichomonads have also been suggested as a pathogenic mechanism because cell-free filtrates have also showed similar cytopathic effect (22). Hence, the use of cell or tissue culture offers a means for analysis of the mechanisms of $T$ vaginalis pathogenicity.

Diagnosis based on clinical presentation is neither sensitive nor specific, whereas wet preparation lacks sensitivity. The cell culture technique is not preferred because the pres- ence of microbial flora in the vagina may interfere with the isolation and identification of the parasites. The use of selective media incorporating appropriate antibiotics to suppress vaginal flora is sensitive and specific and, consequently, is more sensitive than microscopic or other in vivo techniques. However, cell culture is expensive, not readily available, and is not amenable to rapid diagnosis. These limitations have prompted several attempts to detect circulating antibodies in the serum and secretory antibodies in urethral and vaginal exudate.

\section{IMMUNE-BASED TECHNIQUES}

Circulating antibodies to $\mathrm{T}$ vaginalis in infected patients have been demonstrated by agglutination (23), complement fixation (24), indirect hemagglutination, gel diffusion (25), fluorescent antibody (26) and ELISA (27). Most of these studies showed the presence of immunoglobulin (Ig) $G$ rather than IgM in the sera of infected patients.

Using a mouse model of vaginal $\mathrm{T}$ vaginalis infection, protection from infection was demonstrated when the serum samples showed the presence of IgG class antibodies at a titre of $1: 100$ or more. This suggests a possible role of the humoral response in protection. However, humoral response has not been shown to protect humans. The role of cell-mediated response cannot be excluded because parasite killing independent of antibodies has also been observed (28-30).

The antibody response to the pathogen is influenced by various factors such as the nature of the antigen or pathogen, its live or inactivated form, inoculum size, and the frequency and length of exposure. Alderete et al $(31,32)$ observed that all strains of $T$ vaginalis synthesize but do not express certain high molecular weight proteins and only the trichomonads with the surface-exposed antigen induce an antibody response.

Cogne et al (33) used hemagglutination, immunofluorescence and ELISA to study the systemic antibody response to these parasites. They observed that ELISA showed better correlation with past and current infection and suggested its use as an alternative method in the diagnosis of infection.

Alderete (34) used ELISA to detect circulating antibodies by using whole cell and aqueous protein extracts as antigen. He also detected antibodies in patients with no previous or current history of infection. This could be due to the presence of natural antibodies. Bozner et al (35) showed that immunoprecipitation using protein A-bearing Staphylococcus aureus combined with electrophoresis in gelatin-polyacrylamide gels as a technique for demonstration of antibodies was superior to ELISA because no purification of $\mathrm{T}$ vaginalis antigen is required.

\section{DNA TECHNIQUES}

With recent advances in recombinant DNA technology, genes from pathogenic microorganisms have been cloned and used as probes for the detection of pathogens from clinical specimens. Wang and Wang (36) characterized the genome of $\mathrm{T}$ vaginalis and reported that it consists of approximately $2.5 \times 10^{7}$ base pairs with a high degree of repetitive sequences. This has been supported by the findings of Paces et al (37). 
They showed that all isolates of T vaginalis had $10^{2}$ to $10^{3}$ repeats of TV-E650 and used this in the detection of $\mathrm{T}$ vaginalis in clinical specimens.

Rubino et al (38) found a $2.3 \mathrm{~Kb} \mathrm{~T}$ vaginalis DNA fragment in all strains obtained from diverse geographic areas. They used this clone as a probe for the detection of T vaginalis DNA in vaginal exudates using a dot-blot hybridization technique. The probe was specific for $\mathrm{T}$ vaginalis DNA, did not react with other microbial flora of the vaginal tract, and was as sensitive as culture.

\section{PATHOGENESIS OF T VAGINALIS INFECTION}

Two schools of thought exist regarding the pathogenesis of $\mathrm{T}$ vaginalis, ie, contact-dependent (39) and contact-independent (21) mechanisms. It is likely that both are important. Graves and Gardner (40) showed that adherence, contactindependent factors, hemolysis, acquisition of host macromolecules by the organisms and the host response are all important factors in the pathogenicity of this parasite.

Four adhesin proteins ranging from $65 \mathrm{kDa}$ to $21 \mathrm{kDa}$ or less, are associated with cytadherence (40-42). These adhesins were not identified on Thermoproteus tenax, a nonpathogenic trichomonad. Protease treatment diminished cytoadherence, suggesting that these proteins are unique and important factors in the pathogenicity of $\mathrm{T}$ vaginalis. Furthermore, cysteine protease was found to be necessary for parasite adherence to epithelial cells. The adherence was inhibited when the parasites were treated with inhibitors of trichomonad cysteine protease. Similar findings were observed in our study using McCoy cell monolayer. When treated with $\mathrm{N}$ - $\alpha$-p-tosyl-L-lysine chloromethyl ketone (TLCK), a cysteine protease inhibitor, the parasites failed to disrupt the monolayer for more than $8 \mathrm{~h}$, whereas untreated parasites consistently disrupted the monolayer in under $5 \mathrm{~h}$.

Coombs and North (43) and Lockwood et al $(44,45)$ have shown the presence of multiple proteases in cell lysates of $T$ vaginalis. Garber and Lemchuk-Favel (46), using an immunoblotting technique, have demonstrated the presence of two extracellular cysteine proteases $(60 \mathrm{kDa}$ and $30 \mathrm{kDa})$ from the cell-free filtrate of $\mathrm{T}$ vaginalis. The $60 \mathrm{kDa}$ protease was produced by all $12 \mathrm{~T}$ vaginalis isolates used in the study. It was present in vaginal washes of mice and humans with active $T$ vaginalis infection but absent in the vaginal washes of noninfected or successfully treated humans or mice. The detection of this factor, observed in pathogenic isolates only, may be a key step in studying pathogenesis and it may also serve as a diagnostic tool in active $\mathrm{T}$ vaginalis infection.

Krieger et al (47) reported that beta-hemolysin may be a virulence factor for $\mathrm{T}$ vaginalis. Many bacteria (48) and protozoa $(49,50)$ have been shown to produce this virulence marker. Hemolysis may be important in providing nutrients from lysed erythrocytes because trichomoniasis is frequently exacerbated by menses. Fiori et al (51) and Arroyo et al (52) observed surface proteins in the range of $140 \mathrm{kDa}$ to $33 \mathrm{kDa}$ involved in hemolysis.

Contact-independent factors are also important in pathogenesis. Garber et al (22) demonstrated the presence of a 200
KDa contact-independent factor, a glycoprotein that causes monolayer cell detachment. This cell detaching factor (CDF) was observed in all 12 clinical isolates and a significant association of CDF production with clinical presentation was observed (53). The absence of this marker in Pentatrichomonas hominis suggests that it is a virulence marker. Many other studies also support a role of contact-independent cytotoxic mechanisms since the subepithelial vascularity seen in trichomoniasis does not always correlate with the number of parasites. Furthermore, supernatants from cultures of $\mathrm{T}$ vaginalis can cause a cytopathic effect in cell cultures $(21,39)$.

The presence of these proteins in all the isolates of $\mathrm{T}$ vaginalis and in vivo experiments using a mouse model demonstrating that these proteins are immunogenic suggests that the proteins could be possible vaccine candidates or useful for diagnostic testing.

\section{ROLE OF ANTIBODY IN PATHOGENESIS}

$\mathrm{T}$ vaginalis possesses the ability to adsorb host plasma proteins that may have a function in nutrition or protection of the parasites. The host molecules may coat both the host and parasite components required for complement-mediated lysis. Specific local antibodies of IgA and IgG class have been identified in the cervicovaginal secretions of most infected individuals (54). Vaginal antitrichomonal antibodies have also been detected using the following techniques: ${ }^{125}$ I-labelled antihuman IgA techniques (54), immunofluorescence (55) and ELISA (56).

IgA prevents adherence and subsequent uptake of pathogens by epithelial cells and it may potentiate opsonization of the parasites by IgG. However, Ackers et al (54) observed that antitrichomonas IgA was absent in the vaginal fluid of many patients with active $\mathrm{T}$ vaginalis infection, and $\mathrm{Su}(55)$ suggested that no correlation exists between the severity of the disease and IgG antibody level in the secretions. Using a mouse model, we were able to detect IgG and IgA antibodies in the vaginal washes of experimentally infected mice. This suggests that this model may be useful in studying various strategies to enhance the host immune response to infection.

Alderete (34) reported the presence of low titre IgA and IgG in vaginal secretions of infected females. This lack of correlation between antitrichomonal antibodies in vaginal washes and clinical picture of infection could be due to host plasma proteins that coat the parasites. This could influence the immune response and represent a mechanism by which the immune factors in the vagina are neutralized (34).

Extracellular protease production by $\mathrm{T}$ vaginalis may constitute a potential virulence factor by altering or inactivating a variety of host proteins. Protease production was observed in aerobic and anaerobic microorganisms found in the lower and upper genital tract sites of women with premature rupture of membrane and chorioamnionitis (58). Recently, Provenzano and Alderete (59) showed that $\mathrm{T}$ vaginalis is capable of degrading human immunoglobulins, and the presence of antiprotease antibodies in both serum and vaginal secretions of women was seen in active trichomoniasis. 
Lockwood et al (45) and Garber and Lemchuk-Farel (60) found extracellular cysteine protease in culture medium and have suggested that these enzymes are also released from parasites in vivo. Proteases that degrade antibodies have been found in other protozoan parasites. Talbot et al (61) showed that Trichomonas foetus, a bovine trichomonad, releases extracellular cysteine protease that cleaves IgG class 1 and 2, along with other host proteins. Similar immunoglobulin degradation by Streptococcus sanguis and Neisseria gonorrhoeae was observed by Plaut et al (62). This could explain the possible role of protease in pathogenesis. Pathogenic trichomonad strains possess proteases that are required for adherence and the release of these proteases degrade immunoglobulins which can result in an alteration of the host immune response to infection.

In our preliminary experiments using a mouse model, we observed that cysteine proteinase is immunogenic in nature and that antibodies raised against this protease reacted with whole cell $\mathrm{T}$ vaginalis in a dot-blot immunoassay. We also observed that antiprotease antiserum could detect $10^{3} \mathrm{~T}$ vaginalis/mL. This is more sensitive than the wet preparation. Bozner et al (35) also detected IgG specific for trichomonad cysteine protease in patients with trichomoniasis. This suggests that the detection of specific $\mathrm{T}$ vaginalis protease is a useful diagnostic tool.

Monoclonal antibodies to these immunogens could help to detect $\mathrm{T}$ vaginalis isolates from clinical specimens by using either a single or a group of monoclonal antibodies. Torian et al (63) prepared eight monoclonal antibodies of which one, directed against a $62 \mathrm{kDa}$ polypeptide, reacted with all the isolates of T vaginalis. Krieger et al (15) obtained a group of nine monoclonal antibodies by using four isolates of $\mathrm{T}$ vaginalis as immunogens. T vaginalis isolates from the diverse geographic areas of North America reacted with at least one of the nine monoclonal antibodies. A pool of two broadly reactive monoclonal antibodies identified all 88 isolates tested.

\section{REFERENCES}

1. Brown MT. Trichomoniasis. Practitioner 1972;209:639-44.

2. Catterall RD. Trichomonal infection of the genital tract. Med Clin North Am 1972;56:1203-9.

3. Kreiger JN. Urologic aspects of trichomoniasis. Invest Urol 1981;18:411-7.

4. Wisdom AR, Dunlop EMC. Trichomoniasis. Study of the disease and its treatment. Br J Vener Dis 1965;41:90-6.

5. Grice AC. Vaginal infection causing spontaneous rupture of the membrane and premature delivery. Aust NZ J Obstet Gynecol 1974;14:156-8.

6. Pilawski Z, Malecha J. Trichomonads and the pregnancy: Therapeutic problems. Wiad Parazytol 1983;29:187-90.

7. Cotch MF. Effect of Trichomonas vaginalis carriage on pregnancy outcome. $9^{\text {th }}$ International Society for STD Research. Banff, October, 1991. (Abst)

8. Draper D, Jones W, Richter R, James J, Todd J, McGregor J. Effect of Trichomonas vaginalis on fetal membranes bursting strength. 9th International Society for STD Research. Banff, October, 1991. (Abst)

9. Read JS, Klebanoff MA. Sexual intercourse during pregnancy and preterm delivery: Effects of vaginal microorganisms. Am J Obstet Gynecol 1993;168:514-9.

10. Cameron DW, Padian NS. Sexual transmission of HIV and the epidemiology of other sexually transmitted diseases. AIDS 1990;4:S99-103.

11. McMillan A. Laboratory diagnostic methods and cryopreservation
Lisi et al (64) used a monoclonal antibody specific for $65 \mathrm{kDa}$ surface polypeptide of T vaginalis as the capture antibody in sandwich ELISA technique. They suggested that this technique was more sensitive than wet preparation and comparable with routinely used culture technique in the diagnosis of $\mathrm{T}$ vaginalis with the added advantage of identifying nonviable parasites.

The use of monoclonal antibody in the treatment of trichomoniasis was suggested by Moav et al (65). They observed that anti-T vaginalis antibodies of IgG3 subclass played a protective role against the parasites by lysing $\mathrm{T}$ vaginalis in the presence of complement. The administration of a monoclonal antibody linked to a pharmaceutically acceptable carrier could prove to be a good alternative therapeutic agent, especially in the treatment of metronidazole-resistant strains.

Infections due to $\mathrm{T}$ vaginalis are never life threatening; however, their link to HIV transmission (10), premature delivery (9), etc, cannot be dismissed. Moreover, the symptoms associated with this common infection can be physically and psychologically distressing. The treatment of trichomoniasis was revolutionized by the introduction of metronidazole in 1960 (66). The drug has proved more than a match for all alternative therapies to date and has consolidated its position as the drug of first choice in the treatment of trichomoniasis. Increasingly, however, $\mathrm{T}$ vaginalis is developing resistance to this therapy. With trichomoniasis most men are considered the carriers and women the reservoir of the infection, thus it is necessary to treat both the partners to eliminate the parasite and avoid the high incidence of relapse. Preliminary data from a mouse model does suggest the feasibility of vaccine strategy to prevent disease. Until this is available, the best means to prevent the spread of T vaginalis is by safe sex practices. However, accurate and practicable methods of detecting $\mathrm{T}$ vaginalis in genital secretions are also essential for effective diagnosis and treatment, leading to eradication of the trichomonal infection.

of trichomonads. In: Honigberg BM, ed. Trichomonads Parasitic in Humans. New York: Springer-Verlag, 1990:297-310.

12. Levett PN. A comparison of five methods for the detection of Trichomonas vaginalis in clinical specimens. Med Lab Sci 1980;37:85-8.

13. Greenwood JR, Kirk-Hillaire K. Evaluation of acridine orange stain for the detection of Trichomonas vaginalis in vaginal specimens. J Clin Microbiol 1981;14:699.

14. Summers JL, Ford NL. The Papanicolaou smears as a diagnostic tool in male trichomoniasis. J Urol 1972;107:840-2.

15. Krieger JN, Holmes KK, Spence MR, Rein MF, McCormack WM, Tam MR. Geographic variation among isolates of Trichomonas vaginalis: Demonstration of antigenic heterogeneity by using monoclonal antibodies and the indirect immunofluorescence technique. J Infect Dis 1985;152:979-84.

16. Bickley LS, Krisher KK, Punsalang M, Trupei MA, Reichman RC, Menegus MA. Comparison of direct fluorescent antibody, acridine orange, wet-mount and culture for detection of Trichomonas vaginalis in women attending a public sexually transmitted diseases clinic. Sex Transm Dis 1989;16:127-31.

17. Hogue MJ. The effect of Trichomonas vaginalis on tissue-culture cells. Am J Hyg 1943;37;142-52.

18. Garber GE, Sibau L, Roy MA, Proctor EM, Shaw CE, Bowie WR. Cell culture compared with broth for detection of Trichomonas vaginalis. J Clin Microbiol 1987;25:1275-9. 
19. Kulda J. The effect of different species of trichomonads on monkey kidney cell cultures. Folia Parasitol 67;14:295-310.

20. Alderete JF, Pearlman E. Pathogenic Trichomonas vaginalis cytotoxicity to cell culture monolayers. Br J Vener Dis 1984;60:99-105.

21. Pindak FF, Gardner WA. Contact-independent cytotoxicity of Trichomonas vaginalis. Genitourin Med 1993;69:35-40.

22. Garber GE, Lemchuk-Favel LT, Bowie WR. Isolation of a cell-detaching factor of Trichomonas vaginalis. J Clin Microbiol 1989;27:1548-53.

23. Teras J, Nigesen U, Jaakmees H, Roigas E, Tompel H. The agglutinogenic properties of Trichomonas vaginalis in human organism. Wiad Parazytol 1966;12:370-7.

24. Jaakmees H, Teras J, Roigas E, Nigesen U, Tompel H. Complement-fixing antibodies in the blood sera of men infested with Trichomonas vaginalis. Wiad Parazytol 1966;12:378-84.

25. Mathews HM, Healy GR. Evaluation of two serologic tests for Trichomonas vaginalis infection. J Clin Microbiol 1983;17:840-3.

26. Mason PR. Serodiagnosis of Trichomonas vaginalis infection by the indirect fluorescent antibody test. J Clin Pathol 1979;32:1211-5.

27. Sibau L, Bebb D, Proctor EM, Bowie WR. Enzyme-linked assay for the diagnosis of trichomoniasis in women. Sex Transm Dis 1987;14:216-20.

28. Adler S, Sadowsky A. Intradermal reaction in trichomonas infection. Lancet 1943;252:867-8.

29. Mason PR, Patterson BA. Proliferative response of human lymphocytes to secretory and cellular antigens of $\mathrm{T}$ vaginalis. J Parasitol 1985;71:265-8.

30. Landolfo S, Martinotti MG, Martinetto P, Forni G. Natural cell-mediated cytotoxicity against $\mathrm{T}$ vaginalis in the mouse. 1 . Tissue, strain, age distribution and some characteristics of the effector cells. J Immunol 1979;124:508-14.

31. Alderete JF, Suprun-Brown L, Kasmala L, Smith J, Spence M. Heterogeneity of Trichomonas vaginalis and discrimination among trichomonas isolated and subpopulations with sera of patients and experimentally infected mice. Infect Immun 1985;49:463-8.

32. Alderete JF, Kasmala L, Metcalfe E, Garza G. Phenotypic variation and diversity among Trichomonas vaginalis isolates and correlation of phenotype with trichomonal virulence determinants. Infect Immun 1986;53:285-93.

33. Cogne M, Brasseur P, Ballet J. Detection and characterization of serum antitrichomonal antibodies in urogenital trichomoniasis. J Clin Microbiol 1985;21:588-92.

34. Alderete JF. Enzyme linked immunosorbent assay for detecting antibody to Trichomonas vaginalis: Use of whole cells and aqueous extract as antigen. Br J Vener Dis 1984;60:164-70.

35. Bozner P, Gombosova A, Valent M, Demes P, Alderete JF. Proteinase of Trichomonas vaginalis: Antibody response in patients with urogenital trichomoniasis. Parasitol 1992;105:387-91.

36. Wang AL, Wang CC. Isolation and characterization of DNA from Tritrichomonas foetus and Trichomonas vaginalis. Mol Biochem Parasitol 1985;14:323-35.

37. Paces J, Urbankova V, Urbanek P. Cloning and characterization of a repetitive DNA sequence specific for Trichomonas vaginalis. Mol Biochem Parasitol 1992;54:247-57.

38. Rubino S, Muresu R, Rappelli P, et al. Molecular probe for identification of Trichomonas vaginalis DNA. J Clin Microbiol 1991;29:702-06

39. Pindak FF, Gardner WA. Contact-independent cytotoxicity of Trichomonas vaginalis. Genitourin Med 1993;69:35-40.

40. Graves A, Gardner WA. Pathogenicity of Trichomonas vaginalis. Clin Obstet Gynecol 1993:36:145-52.

41. Alderete JF, Garza GE. Identification and properties of Trichomonas vaginalis proteins involved in cytoadherence. Infect Immun 1988;56:28-33.

42. Arroyo R, Alderete JF. Trichomonas vaginalis surface proteinase activity is necessary for parasite adherence to epithelial cells. Infect Immun 1989;57:2991-7.

43. Coombs GH, North MJ. An analysis of the proteinases of Trichomonas vaginalis by polyacrylamide gel electrophoresis. Parasitol 1983;86:1-6.

44. Lockwood BC, North MJ, Coombs GH. Trichomonas vaginalis,
Trichomonas foetus and Trichomitus batrachorum: Comparative proteolytic activity. Exp Parasitol 1984;58:245-53.

45. Lockwood BC, North MJ, Scott KI, Bremner AF, Coombs GH. The use of a highly sensitive electrophoresis method to compare the proteinase of trichomonads. Mol Biochem Parasitol 1987;24:89-95.

46. Garber GE, Lemchuk-Favel LT. Analysis of the extracellular proteases of Trichomonas vaginalis. Parasitol Res 1994;80:361-5.

47. Krieger JN, Poisson MA, Rein MF. Beta-hemolytic activity of Trichomonas vaginalis correlates with virulence. Infect Immun 1983;41:1291-5.

48. Freer JH, Arbuthnott JP. Biochemical and morphologic alterations of membranes by bacterial toxins. In: Bernheimer AW, ed. Mechanisms in Bacterial Toxicology. New York: John Wiley and Sons Inc, 1976:103-93.

49. Lopez-Revilla R, Said-Fernandez S. Cytopathogenicity of Entamoeba hystolytica: Hemolytic activity of trophozoite homogenates. Am J Trop Med Hyg 1980;29:200-12.

50. Tizar IR, Sheppard J, Neilsen K. The characterization of a second class hemolysins from Trypanosoma brucei. Trans R Soc Trop Med Hyg 1978;72:198-200.

51. Fiori PI, Rappelli P, Rocchigiani AM, Cappuccinelli P. Trichomonas vaginalis haemolysis: Evidence of functional pores formation on red cell membranes. WHEMS Microbiol Lett 1992;109:13-8.

52. Arroyo R, Engbring J, Alderete JF. Molecular basis of host epithelial cell recognition by Trichomonas vaginalis. Mol Microbiol 1992;6:853-62.

53. Garber GE, Lemchuk-Favel LT. Association of production of cell-detaching factor with the clinical presentation of Trichomonas vaginalis. J Clin Microbiol 1990;28:2415-7.

54. Ackers JP, Lumsden WHR, Catterall RD, Coyle R. Antitrichomonal antibody in the vaginal secretions of women infected with T vaginalis. Br J Vener Dis 1975;51:319-23.

55. Su KE. Antibody to Trichomonas vaginalis in human cervicovaginal secretions. Infect Immun 1982;37:852-7.

56. Street DA, Taylor-Robinson D, Ackers JP, Hanna NF, McMillan A. Evaluation of an enzyme-linked immunosorbent assay for the detection of antibody to Trichomonas vaginalis in sera and vaginal secretions. Br J Vener Dis 1982;58:330-3.

57. Peterson KM, Alderete JF. Host plasma proteins on the surface of pathogenic Trichomonas vaginalis. Infect Immun 1982;37:755-62.

58. McGregor JA, Lawellin D, France-Butt A, Todd JK, Makowski EL. Protease production by microorganisms associated with reproductive tract infection. Am J Obstet Gynecol 1986;154:109-14.

59. Provenzano D, Alderete JF. Analysis of immunoglobulindegrading cysteine proteinases of Trichomonas vaginalis. Infect Immun 1995;63:3388-95.

60. Garber GE, Lemchuk-Favel LT. Characterization and purification of extracellular proteases of Trichomonas vaginalis. Can J Microbiol 1989;35:903-9.

61. Talbot JA, Nielsen K, Corbeit LB. Cleavage of proteins of reproductive secretions by extracellular proteinases of Trichomonas foetus. Can J Microbiol 1991;37:384-90.

62. Plaut AG, Gilbert JV, Wistar R. Loss of antibody activity in human immunoglobulin A exposed to extracellular immunoglobulin A proteases of Neisseria gonnorrhoeae and Streptococcus sanguis. Infect Immun 1977;17:130-5.

63. Torian BE, Connelly RJ, Stephens RS, Stibbs HH. Specific and common antigens of Trichomonas vaginalis detected by monoclonal antibodies. Infect Immun 1984:43:270-5.

64. Lisi PJ, Dandero RS, Kwiatkoski D, Spence MR, Rein MF, Alderete JF. Monoclonal-antibody-based enzyme-linked immunosorbent assay for Trichomonas vaginalis. J Clin Microbio 1988;26:1684-6.

65. Moav N, Draghi E, David A, Gold D. Anti-Trichomonas vaginalis monoclonal antibodies inducing complement-dependent cytotoxicity. Immunology 1988;63:63-9.

66. Durel P, Couture J, Bassoullet M. Systemic treatment of human trichomoniasis with a derivative of nitro-imidazole. 8823 R.P. Br J Vener Dis 1960;36:21-6. 


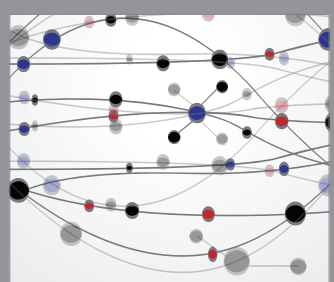

The Scientific World Journal
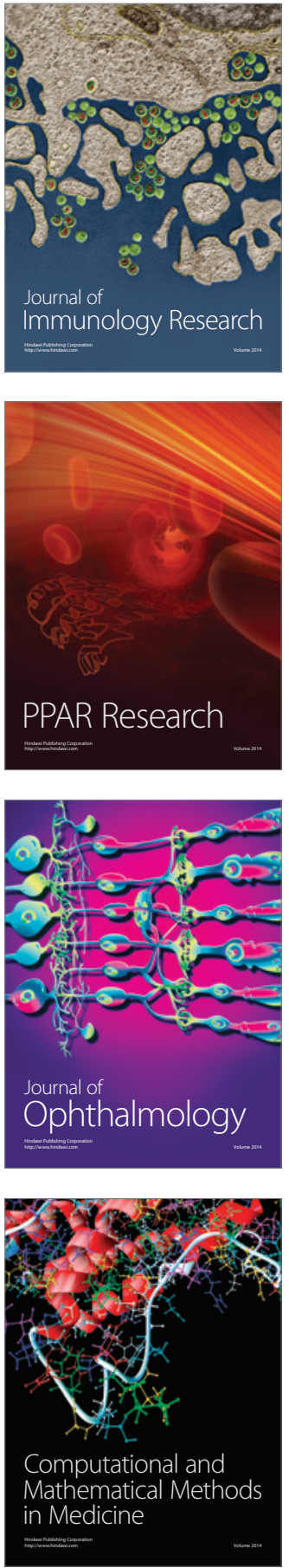

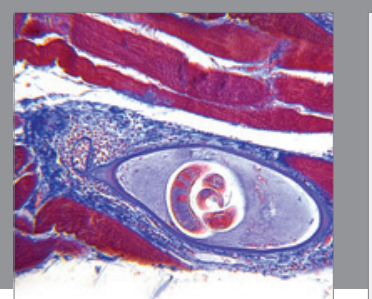

Gastroenterology Research and Practice

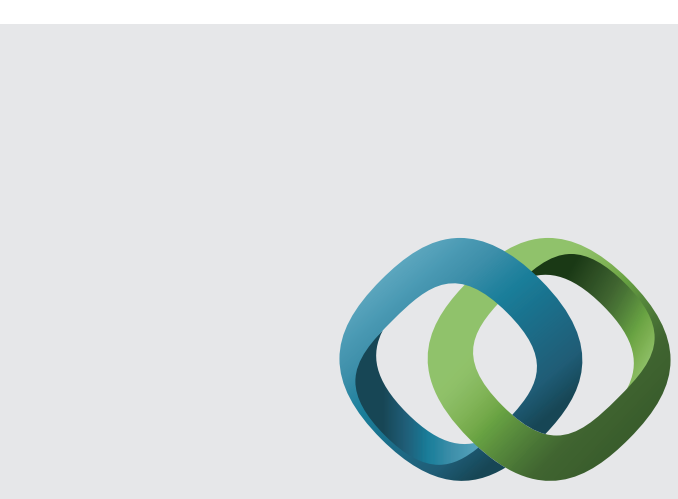

\section{Hindawi}

Submit your manuscripts at

http://www.hindawi.com
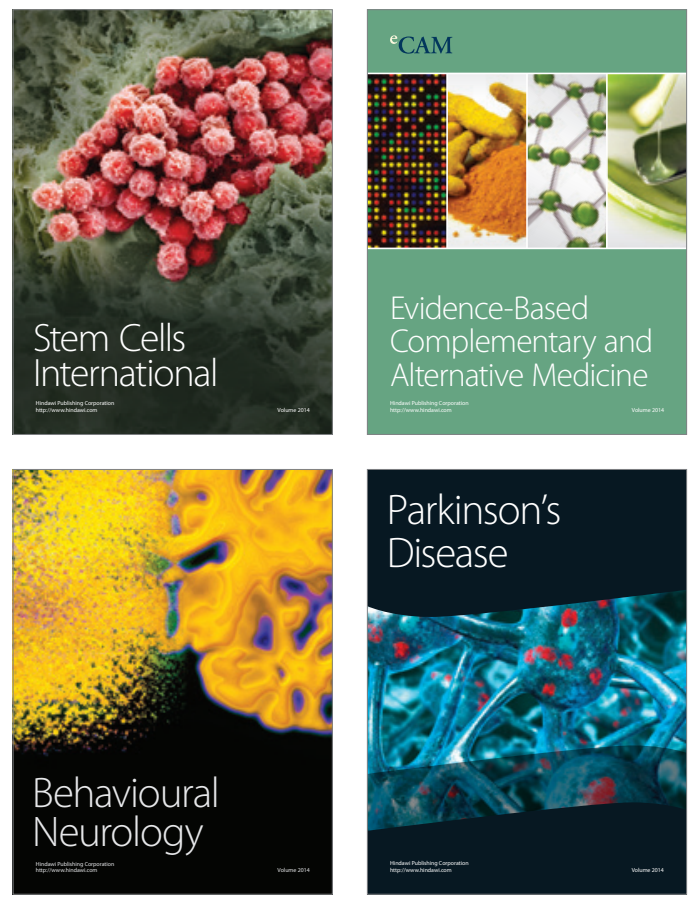
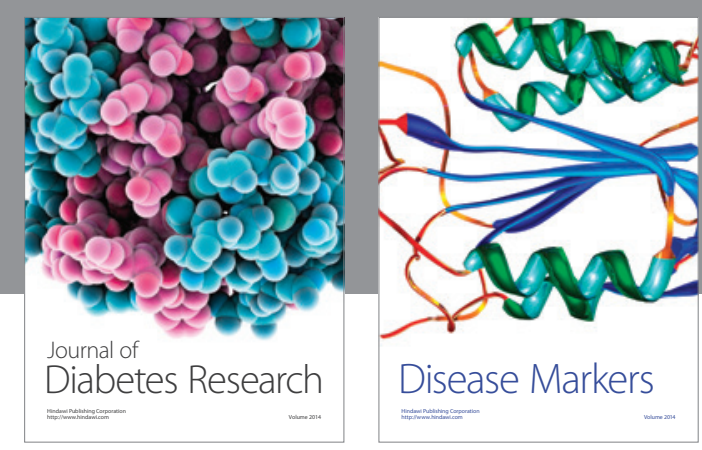

Disease Markers
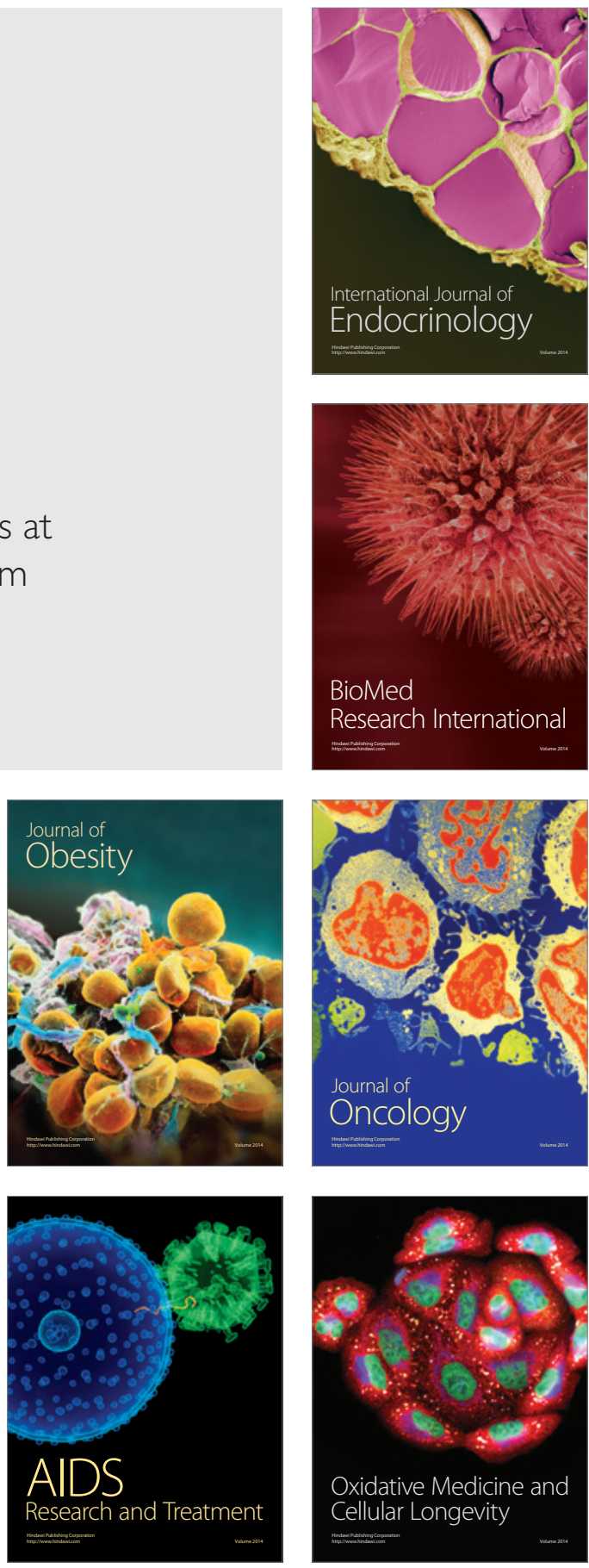